\title{
Sistem Informasi Museum Negeri Provinsi Sumatera Selatan
}

\author{
Novri Hadinata $^{[1]}$, Edi Supratman ${ }^{[2]}$ \\ Universitas Bina Darma, Jln.Jenderal Ahmad Yani No.02. Palembang ${ }^{[1][2]}$ \\ novri_hadinata@binadarma.ac.id ${ }^{[1]}$, Edy_supratman@binadarma.ac.id ${ }^{[2]}$
}

\begin{abstract}
Abstrak- Museum Balaputra Dewa adalah tempat rekreasi yang murah dan mendidik yang ada dikota Palembang . Akan tetapi, orang-orang jarang sekali mau berkunjung ke museum dikarenakan kurangnya informasi tentang museum tersebut Balaputra Dewa. Peran museum sangatlah signifikan dalam pengembangan wawasan serta pengetahuan yang sangat berguna untuk menciptakan pelestarian terhadap warisan budaya akan tetapi juga untuk melestarikan makna yang ada pada sistem, nilai dan norma. Dimana warisan budaya yang ada pada masa lampau tidak mudah untuk ditinggalkan, Oleh karna itu untuk dapat memberikan informasi yang dapat didunakan sebagai media pendidikan peneliti berencana membangun sebuah sistem informasi berbasis web Museum Negeri Sumatera selatan . Sistem Informasi ini dibangun dengan pendekatan web Engineering bahasa pemograman PHP, CSS, dan HTML dimana didalam sistem informasi ini nantinya memuat seluruh benda - sejarah koleksi dari museum Balaputra dewa dalam bentuk visual. Sistem informasi ini diharapkan dapat memberikan informasi mengenai benda - benda sejarah yang ada di Museum Balaputra Dewa dan dapat dijadikan sebagai media pendidikan bagi masyarakat mengenai benda - benda sejarah yang tersimpan dimuseum negeriSumatera Selatan.
\end{abstract}

Kata Kunci-Museum, Sistem Informasi, web engineering

\section{PENDAhUluan}

Museum adalah lembaga yang diperuntukkan bagi masyarakat umum. Museum berfungsi mengumpulkan, merawat, dan menyajikan serta melestarikan warisan budaya masyarakat untuk tujuan studi, penelitian dan kesenangan atau hiburan Berdasarkan Peraturan Pemerintah RI No. 19 Tahun 1995, museum adalah lembaga, tempat penyimpanan, perawatan, pengamanan dan pemanfaatan benda-benda bukti materiil hasil budaya manusia serta alam dan lingkungan nya guna menunjang upaya perlindungan dan pelestarian kekayaan budaya bangsa.

Musem Negeri Provinsi Sumatera Selatan (Museum Balaputra Dewa) ini dibangun dengan arsitektur tradisional Palembang pada areal seluas 23.565 meter persegi. Di museum ini terdapat sekitar 3.800 koleksi, terdiri berbagai macam jenis koleksi yang diklasifikasikan menjadi 10 jenis, di antaranya Geologika, Biologika, barang-barang tradisional Palembang, ofset binatang dari berbagai daerah di Sumatera Selatan dan beberapa miniatur rumah di pedalaman. Terdapat pula replika prasasti dari arca kuno yang pernah ditemukan di Bukit Siguntang. Koleksi arkeologi Museum Negeri Provinsi Sumsel ini dapat diklasifikasikan menjadi tiga periodisasi masa, yakni masa pra sejarah, masa pra Sriwijaya dan masa Sriwijaya.

Museum memiliki potensi luar biasa untuk pengembangan dan dorongan terhadap pencapaian pendidikan multikultur. Peran museum menghadirkan berbagai dimensi budaya manusia dari setiap ruang dan waktu. Museum merupakan tempat dimana orang mengumpulkan, memajang dan saling tukar berbagai fragmen. Banyak perhatian yang bukan pada topik manusia, seperti ekologi padang pasir, dan ada pula yang memusatkan perhatian pada orang dari sisi perbedaan budaya atau sisi kehidupan. Museum memiliki banyak benda riil, replika, tempat, serta peristiwa .

Rendahnya minat masyarakat untuk berkunjung ke museum khususnya Negeri Sumatera Selatan Merupakan permasalah yang timbul, hal ini menyebabkan kurangnya pengetahuan masyarakat mengenai benda - benda sejarah yang ada di museum. Untuk mendapat kan informasi tentang koleksi museum terkadang terkendala oleh bebrapa masalah diantaranya lokasi untuk mencapai museum yang ada cukup jauh dan museum dianggap masyarakat tempat yang kurang menarik untuk di kunjungi dan sebagian masyarakat menganggap banguana museum itu terkesan angker.

\section{LANDASAN TEORI}

\section{A. Museum}

Berdasarkan definisi yang diberikan International Council of Museums (ICOM), museum adalah lembaga yang permanen, yang melayani kepentingan masyarakat dan kemajuannya, terbuka untuk umum, tidak bertujuan mencari keuntungan, yang mengumpulkan, memelihara, meneliti, memamerkan, mengkomunikasikan benda-benda pembuktian material manusia dan lingkungannya, untuk tujuan-tujuan studi, pendidikan dan rekreasi. Museum dapat dijadikan sebagai studi oleh kalangan akademis, dokumentasi kekhasan masyarakat tertentu, ataupun dokumentasi dan pemikiran imajinatif pada masa depan. Museum berkembang seiring dengan berkembangnya ilmu pengetahuan dan manusia semakin membutuhkan bukti otentik mengenai catatan kebudayaan [1]. 


\section{B. Web}

Web adalah salah satu aplikasi yang berisikan dokumendokumen multi- media (teks, gambar, suara, animasi, video) didalamnya yang menggunakan protokol HTTP (hypertext transfer protocol) dan untuk mengaksesnya menggunakan perangkat lunak yang disebut browser [2].

\section{C. $P H P$}

PHP (PHP: Hypertext Preprocessor) adalah bahasa serverside scripting yang menyatu nengan HTML untuk membuat halaman web yang dinamis. Karena PHP merupakan serverside scripting maka sintaks dan perintah-perintah PHP akan dieksekusi di server kemudian hasilnya dikirimkan ke browser dalam format HTML. Dengan demikian kode program yang ditulis dalam PHP tidak akan terlihat oleh user sehingga keamanan halaman web lebih terjamin. PHP dirancang untuk membentuk halaman web yang dinamis, yaitu halaman web yang dapat membentuk suatu tampilan berdasarkan perintah terkini, seperti menampilkan isi baris data ke halaman web [3].

\section{Web Server}

Web server adalah program aplikasi yang memliliki fungsi sebagai tempat menyimpan dokumen-dokumen web. Jadi semua dokumen baik yang ditulis menggunakan client side scripting maupun server side scripting tersimpan di direktori utama web server (document root) [3].

Basis data adalah kumpulan data yang saling berelasi. Data sendiri merupakan fakta mengenai objek, orang, dan lain-lain. Data dinyatakan dengan nilai (angka, deretan karakter, atau symbol) [4].

\section{E. $M y S Q L$}

MySQL merupakan database yang pertama kali didukung oleh bahasa pemrograman script untuk internet (PHP dan Pearl). MySQL dan PHP dianggap sebagai pasangan software pengembang aplikasi web yang ideal. MySQL lebih sering digunakan untuk membangun aplikasi berbasis web, umumnya pengembangan aplikasinya menggunakan bahasa pemrograman script PHP [2].

\section{Metodologi Penelitian}

Adapun objek pada penelitian ini terfokus pada pembuatan sistem informasi museum Negeri Sumatera selatan berbasis web Sedangkan lokasi penelitian adalah Museum Negeri Sumater Selatan (Museum Balaputra Dewa). Dalam pengembangan sistem ini metode pengembangan Sistem menggunakan metode web engineering, karena metode ini memberikan ide bagi pengembang maupun user tentang cara sistem akan berfungsi dan yang akan dikembangkan. Metode web engineering terdapat 5 ( lima ) tahapan untuk dapat mengembangkan suatu perangkat lunak seperti gambar dibawah ini:

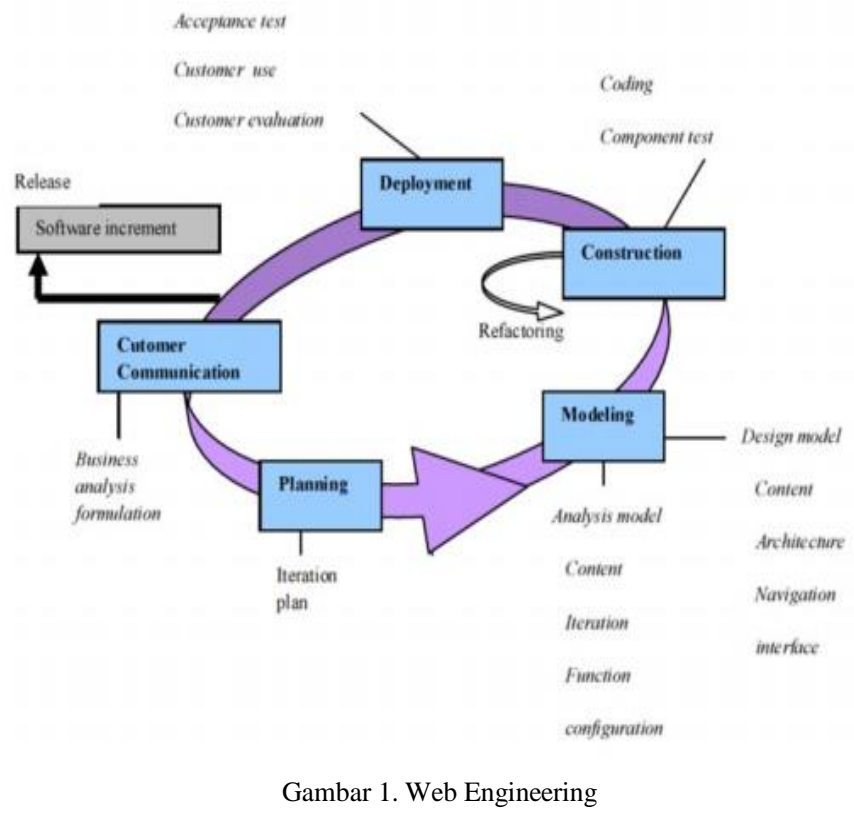

\section{1) Customer Communication}

Komunikasi dalam hal ini terutama terkonsentrasi pada 2 hal, analisa bisnis dan perumusan. Analisa bisnis akan mendefinisikan hal-hal apa saja yang akan termuat di dalam aplikasi web, pada tahapan ini didapatkan informasi - informasi mengenai benda benda koleksi dari museun negeri Provinsi Sumatera Selata dan di peroeh kesimpulan dari tahapan ini adalah sebagai berikut. Museum Balaputradewa memiliki sekitar 3580 buah koleksi yang terdiri dari barang-barang tradisional Palembang, binatang awetan dari berbagai daerah di Sumatera Selatan, beberapa miniature rumah pedalaman, replica prasasti dari arca kuno yang pernah ditemukan di Bukit Siguntang, batu-batu ukir raksasa dari jaman Megalitikum, dan masih banyak lagi.

Koleksi di Museum Balaputradewa dibagi menjadi 10 macam kategori yaitu histografi atau historika (cerita-cerita), etnografi, feologi, keramik, alat-alat teknologi modern, seni rupa (berupa ukiran), flora fauna (biologika) dan geologi serta terdapat rumah limas juga rumah Ulu Ali. Koleksi-koleksi di Museum Balaputradewa ditempatkan pada 3 buah ruang pameran yang dikelompokan menjadi ruang pamer zaman prasejarah, kesultanan Palembang Darussalam dan masa perang kemerdekaan serta tambahan Rumah Limas (rumah/bangunan khas Palembang).

\section{2) Planning}

Perencanaan proyek pengembangan aplikasi web kemudian ditentukan, perencanaan akan terdiri dari pendefinisian pekerjaan dan target waktu atas pekerjaan maupun sub pekerjaan yang ditentukan tersebut.

Estimasi Perangkat lunak didefinisikan sebagai salah satu teknik pendekatan yang bertujuan untuk memperoleh rentang kompleksitas suatu proyek perangkat lunak McConnell(2006). Secara sederhana estimasi yang 
dilakukan pada metode GXP dapat Dirumuskan sebagai berikut.

$$
\text { Estimasi }=\text { Kompleksitas Solusi }+ \text { Resiko Proyek }
$$

Pada Pengembangan sistem Informasi Museum Negeri Sumatera Selatan, perhitungan Estimasi Proyek mengombinasikan aturan perhitungan use case point. dengan model planning poker .

\section{TABEL 1. USER STORIES}

\begin{tabular}{|c|c|c|c|}
\hline $\begin{array}{c}\text { As } \\
\text { \{Actor\} }\end{array}$ & $\begin{array}{l}\text { I Want To } \\
\text { (Action) }\end{array}$ & $\begin{array}{c}\text { So that } \\
\text { (Object) }\end{array}$ & $\begin{array}{c}\text { Estim } \\
\text { ate }\end{array}$ \\
\hline Admin & $\begin{array}{l}\text { Input } \\
\text { Katagori }\end{array}$ & $\begin{array}{l}\text { Sehingga Pengunjung } \\
\text { dapat melihat koleksi } \\
\text { museum berdasarkan } \\
\text { katagori/ jenis koleksi }\end{array}$ & 10 \\
\hline Admin & $\begin{array}{l}\text { Input } \\
\text { koleksi }\end{array}$ & $\begin{array}{l}\text { Sehingga Pengunjug } \\
\text { dapat memperoleh } \\
\text { informasi mengenai } \\
\text { koleksi museum }\end{array}$ & 10 \\
\hline Admin & $\begin{array}{l}\text { Update } \\
\text { Profil } \\
\text { Museum }\end{array}$ & $\begin{array}{l}\text { Sehingga Pengunjung } \\
\text { dapat memperoleh } \\
\text { informasi tentang profil } \\
\text { museum }\end{array}$ & 5 \\
\hline Admin & $\begin{array}{l}\text { Respon } \\
\text { Pertanyaan }\end{array}$ & $\begin{array}{l}\text { Pengunjung dapat } \\
\text { menerima jawaban } \\
\text { seputar keberadaan } \\
\text { museum }\end{array}$ & 10 \\
\hline Pegunjung & $\begin{array}{l}\text { Lihat } \\
\text { Koleksi } \\
\text { Museum }\end{array}$ & $\begin{array}{l}\text { Pengunjung dapat koleksi } \\
\text { museum }\end{array}$ & 5 \\
\hline Pengunjung & $\begin{array}{l}\text { Lihat Profil } \\
\text { museum }\end{array}$ & $\begin{array}{l}\text { Pengunjung dapat } \\
\text { mengetaui keberadaan } \\
\text { dari Museum Negeri } \\
\text { Sumatera selatan }\end{array}$ & 5 \\
\hline Pengunjung & $\begin{array}{l}\text { Input } \\
\text { Pertanyaaan }\end{array}$ & $\begin{array}{l}\text { Pengunjung dapat } \\
\text { memberikan pertanyaan } \\
\text { semutar Museum dan } \\
\text { akan menerimajawaban } \\
\text { dari admin }\end{array}$ & 10 \\
\hline
\end{tabular}

\section{A. Estimasi Kompleksitas Teknis}

Estimasi Kompleksitas teknis pada Sistem Informasi Museum mengacu pada estimmasi User Stories dengan cara perhitungan rating pada faktor Kompleksitas kemudian dikalikan dengan Faktor beban. Faktor Beban adalah suatu koefisien yang ditentukan dari hasil penelitian yang telah dilakukan oleh Carrol. Rating pada umumnya adalah nilai angka yang sebarannya berkisar dari nilai 0 hingga [5]. Nilai 0 memiliki makna bahwa proyek yang dilakukan tidak terkait atau berimplikasi pada efek yang disebut kompleksitas. Sedangkan nilai 5 memiliki makna bahwa hal tersebut sangat berefek pada proyek pengembangan sistem.

Adapun Rating pada faktor kompleksitas sistem penerimaan mahasiswa baru pada AMIK Bina Siriwijaya dapat dilihat pada tabel :
TABEL 2. RATING PADA FAKTOR KOMPLEKSITAS

\begin{tabular}{|l|c|c|c|}
\hline Elemen & Rating & $\begin{array}{c}\text { Faktor } \\
\text { Beban }\end{array}$ & Tfactor \\
\hline $\begin{array}{l}\text { Solusi yang } \\
\text { terdistribusi }\end{array}$ & 4 & 1 & 4 \\
\hline $\begin{array}{l}\text { Kebutuhan Akan } \\
\text { Performa yang } \\
\text { Spesifik }\end{array}$ & 0 & 1 & 0 \\
\hline $\begin{array}{l}\text { Kebutuhan akan } \\
\text { efisiensi yang spesifik }\end{array}$ & 0 & 1 & 0 \\
\hline $\begin{array}{l}\text { Bisnis Proses yang } \\
\text { kompleks }\end{array}$ & 3 & 1 & 3 \\
\hline Kode yang reusable & 2 & 1 & 2 \\
\hline Kemudahan Instalasi & 1 & 0.5 & 0.5 \\
\hline Portabilitas & 5 & 0.5 & 2.5 \\
\hline $\begin{array}{l}\text { Mudah dirubah dan } \\
\text { dikostumisasi }\end{array}$ & 0 & 2 & 0 \\
\hline $\begin{array}{l}\text { Mendukung } \\
\text { penggunaan secara } \\
\text { bersamaan }\end{array}$ & 1 & 1 & 1 \\
\hline $\begin{array}{l}\text { Fitur keaman yang } \\
\text { spesifik }\end{array}$ & 5 & 1 & 5 \\
\hline $\begin{array}{l}\text { Interoperabilitas } \\
\text { dengan aplikasi lain }\end{array}$ & 2 & 1 & 2 \\
\hline $\begin{array}{l}\text { Kebutuhan pelatihan } \\
\text { pengguna yang } \\
\text { spesifik }\end{array}$ & 0 & 1 & 0 \\
\hline & & & 17 \\
\hline
\end{tabular}

Hasil total Tfactor dapat menjadi dasar untuk melakukan perhitungan Technical Complexity Factor (TCF).

$$
\begin{aligned}
T C F & =(\text { TFactor } \times 0.01)+0.6 \\
& =(17 \times 0.01)+0.6 \\
& =0.77
\end{aligned}
$$$$
\begin{aligned}
\text { Software Complexity } & =T C F \times \text { User Story Point } \\
& =0.77 \times 66 \\
& =42.35 \text { Points }
\end{aligned}
$$

didapatkan angka User Story Point sebesar 55 Point,angka tersebut dibandingkan dengan nilai Software Complexity sebesar 42.35 Point

\section{User Story Point( 66 ) > Software Complexity ( 42.35)}

Dengan ini dapat dikatakan Proyek pengembangan ini dapat dikuasai oleh pengembang dikarenakan Faktor kompleksitasnya lebih kecil dibandingkan dengan User Story Points.

\section{B. Estimasi Resiko Proyek}

Risiko Proyek pada GXP dikaitkan dengan hal-hal nonteknis yang terkait dengan aspek manusia. Tabel memperkenalkan Efactor yang merupakan faktor kumulatif dari pengalaman tim pengembang. 
TABEl 3. RATING PADA FAKTOR RESIKO PROYEK

\begin{tabular}{|l|c|c|c|}
\hline Elemen dengan & 5 & 1 & 5 \\
\hline $\begin{array}{l}\text { Terbiasa Aating } \\
\text { Software Proses }\end{array}$ & $\begin{array}{c}\text { Faktor } \\
\text { Beban }\end{array}$ & Efactor \\
\hline $\begin{array}{l}\text { Pengalaman } \\
\text { Pengembangan Aplikasi } \\
\text { Sejenis }\end{array}$ & 2 & 1 & 2 \\
\hline $\begin{array}{l}\text { Pemehaman Paradigma } \\
\text { Objek Oriented }\end{array}$ & 3 & 0.5 & 1.5 \\
\hline Kemempuan Analilis & 5 & 0 & 0 \\
\hline Motivasi Pengguna & 3 & 2 & 6 \\
\hline $\begin{array}{l}\text { Kebutuhan } \\
\text { yang Stabil }\end{array}$ & 5 & -1 & -5 \\
\hline Pekerja Prart Time & 4 & -1 & -4 \\
\hline $\begin{array}{l}\text { Kesulitan } \\
\text { Pemrograman }\end{array}$ & 1 & -1 & -1 \\
\hline $\begin{array}{l}\text { Pengembangan } \\
\text { terdistributif }\end{array}$ & & & $\mathbf{3}$ \\
\hline \multicolumn{1}{|c|}{ Total }
\end{tabular}

Hasil total Efactor dapat menjadi dasar untuk melakukan perhitungan Experience Factor (ECF).

$$
\begin{aligned}
\text { ECF } & =(\text { EF actor } \times(-0.03))+1.4 \\
& =(3 \times(-0.03))+1.4 \\
& =1.31
\end{aligned}
$$

$$
\begin{aligned}
\text { Adjust User Story } & =\text { ECF } \times \text { Software Complexity } \\
& =1,31 \times 42.53 \\
& =55.47 \text { Points }
\end{aligned}
$$

Hasil dari estimasi risiko proyek dapat digunakan sebagai dasar tentukan panjang suatu proyek.

\section{Estimasi Panjang Proyek}

Estimasi panjang proyek pada GXP mengacu pada pendekatan [6] yeng menyatakan tiga kemungkinan pada kurva estimasi yakni bad case, best case, dan good case. Pada pengembangan sistem p panjang proyek dalam hitungan hari mengunakan tiga kemungkinan tersebut.

Langkah pertama dalam perhitungan estimasi panjang proyek adalah menentukan effort rate. Effort rate yaitu suatu nilai yang dibutuhkan untuk mengerjakan suatu Point User Story . Pada penelitian ini nilai pointnya ditentukan sebesar 8 jam Per Point. Nilai tersebut kemudian dikalikan dengan nilai Adjust User Story (55.47) . maka didapatkan angka 443.82 jam, kemudian angka tersebut dibagi dengan jumlah tim sebanyak 2 orang dengan jam kerja yang disepakati adalah 5 jam efektif per hari kerja.

Good case $=($ total Hour $/$ Jumlah Tim $) /$ Waktu Efektif

$$
=(443.82 / 2) / 5
$$$$
=44,38
$$

Best Case $=75 \%$ x $44.38=33.28$ Hari

Bad Case $=125 \%$ x $44.38=55.47$ Hari

TABel 3. Rating Pada Faktor Resiko Proyek

\begin{tabular}{|l|l|l|}
\hline Man-Day Effort & Units & Value \\
\hline Description & Hour / Point & 8 \\
\hline Effort Rate & Point & 55.47 \\
\hline $\begin{array}{l}\text { Adjusted User } \\
\text { Story }\end{array}$ & Jam & 443.82 \\
\hline Total Hour & \multicolumn{2}{|l|}{} \\
\hline Man-Day Effort & Jumlah Tim & 2 \\
\hline Team Member & Unit & Days \\
\hline $\begin{array}{l}\text { Estimation } \\
\text { Chart }\end{array}$ & Hari & 33.28 \\
\hline Best Case & Hari & 44.38 \\
\hline Good Case & Hari & 55.47 \\
\hline Bad Case & &
\end{tabular}

\section{Modelling dan Construction}

Tujuan dari aktivitas ini adalah untuk menjelaskan hal-hal apa saja yang memang diperlukan / dibutuhkan pada aplikasi yang akan dibangun dan solusi yang ditawarkan yang diharapkan dapat menjawab apa yang tersirat dari hasil- hasil analisa dan pengumpulan data. Pembangunan aplikasi web memadukan antara perkembangan teknologi dengan tools pengembangan web yang telah ada, artinya memilih tools yang efektif namun tetap dapat menyesuaikan dengan teknologi yang berkembang saat ini.

\section{1) Use Case Diagram}

Diagram Use Case adalah diagram yang menunjukkan fungsionalitas suatu sistem atau kelas dan bagaimana sistem tersebut berinteraksi dengan dunia luar dan menjelaskan sistem secara fungsional yang terlihat user.

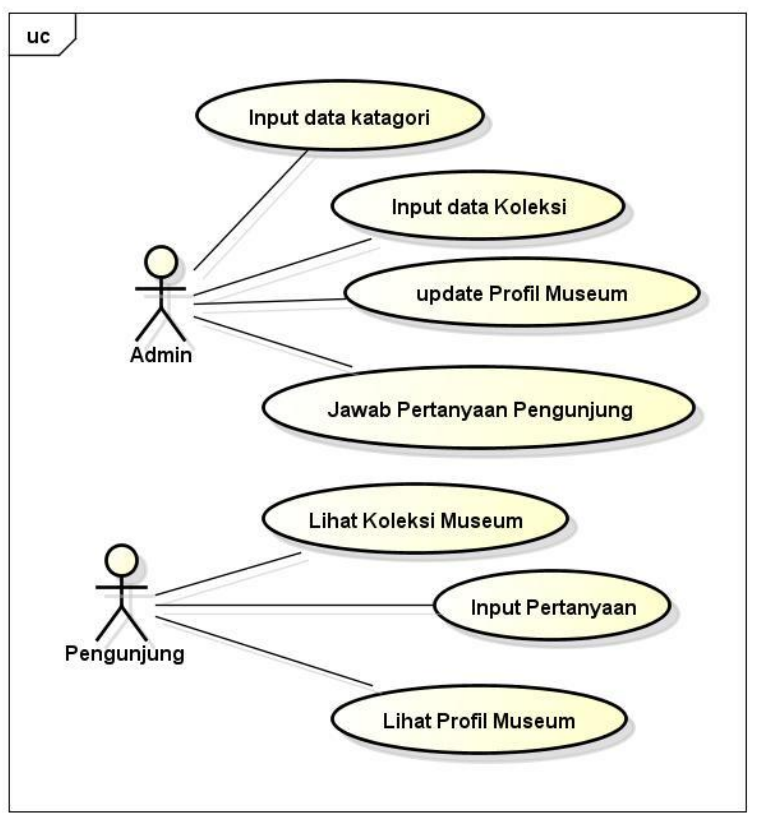

Gambar 2. Langkah-Langkah Penelitian 


\section{2) Activity Diagram}

Activity diagram adalah representasi grafis dari alur kerja tahapan aktivitas. Diagram ini mendukung pilihan tindakan,iterasi dan concurrency.

Berdasarkan usecase diagram diatas baru di atas didapatlah activity diagram sebagai berikut.

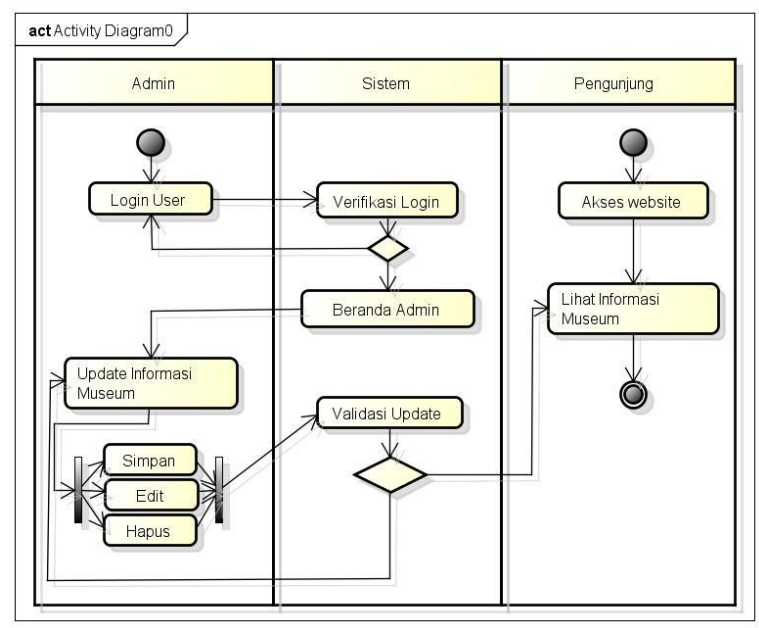

Gambar 3. Activity Diagram

\section{HASIL DAN PEMBAHASAN}

Adapun hasil yang dihasilkan dari tahapan - tahapan yang dilakukan, dihasilkan lah sebuah website museun Negeri Provinsi Sumatera Selatan. Website ini bangun dengan bahasa Pemprograman HTML,CSS,PHP dan basis data dibangun menggunanakan bahasa SQL. Website ini terdiri daldi beberapa halaman yang terbagi menjadi dua, yatu halaman pengunjung dan halaman admin. Berikut ini adalalah beberapa tampilan dari website Museum Negeri Provinsi Sumatera Selatan.
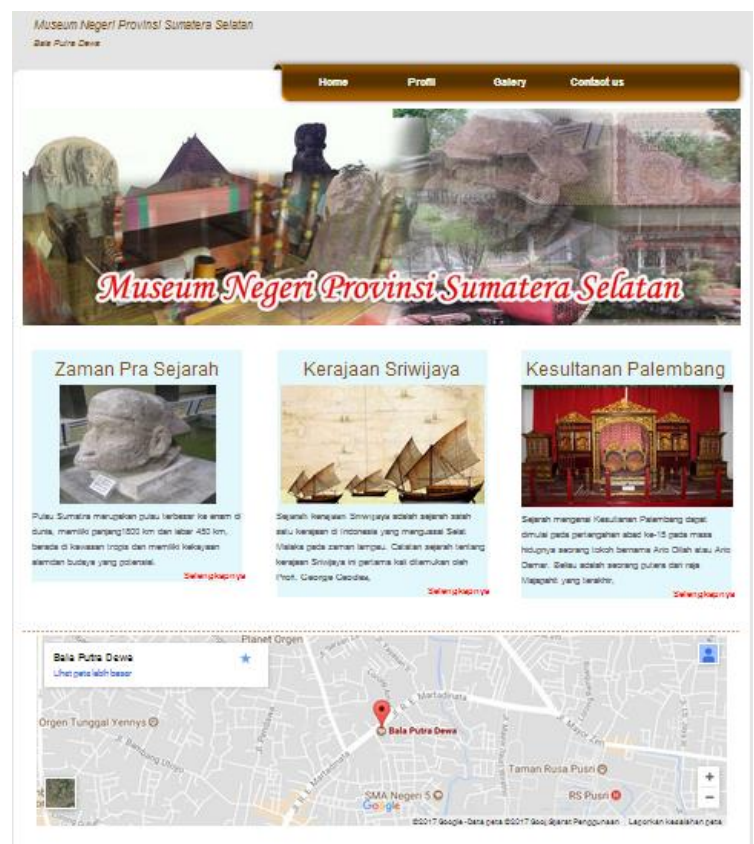

Gambar 4. Halaman Beranda
Tampilan diatas meruakn tampilan beranda pengunjung dimana pada halaman beranda ini berisikan peta lokasi museum dan pambagian kalek si berdasarkan tiga bagian yaitu zaman pra sejarah, Zaman Kerajaan Sriwijaya dan zaman Kesultanan Palembang.

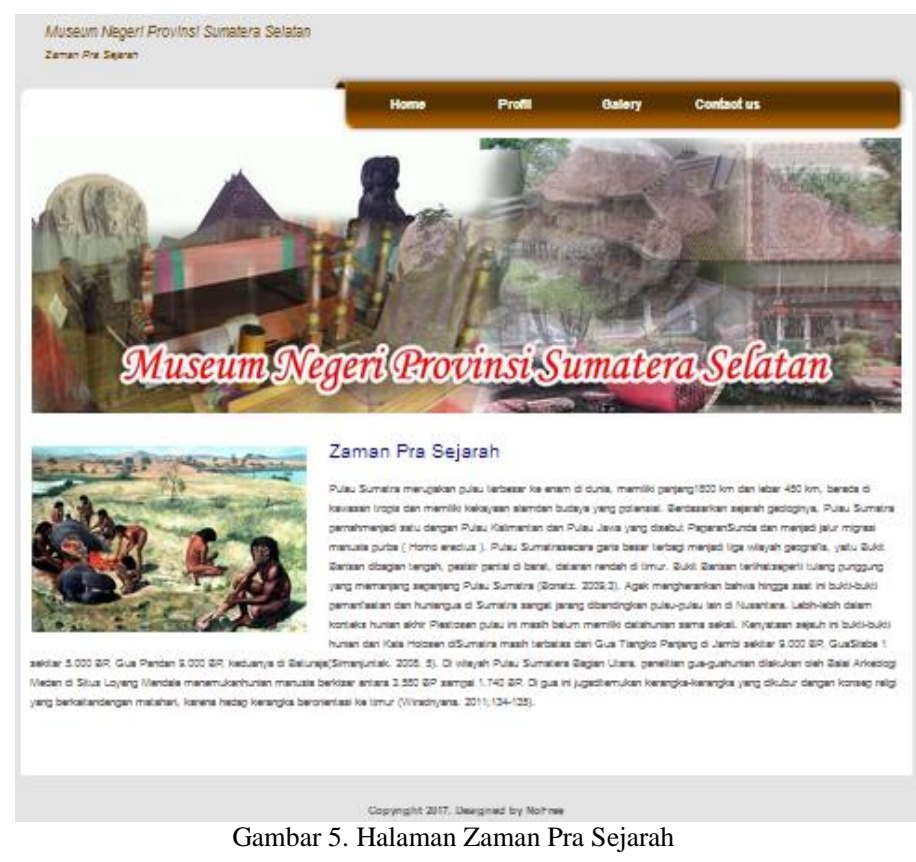

Pada halaman ini memuat sejarah zaman prasejarah yang ada diprovinsi Sumtera Selatan. Pada halam in juga akan memuat foto - foto peninggal zaman pra sejarah yang emnjadi koleksi pada museum negeri provinsi Sumatera selatan.

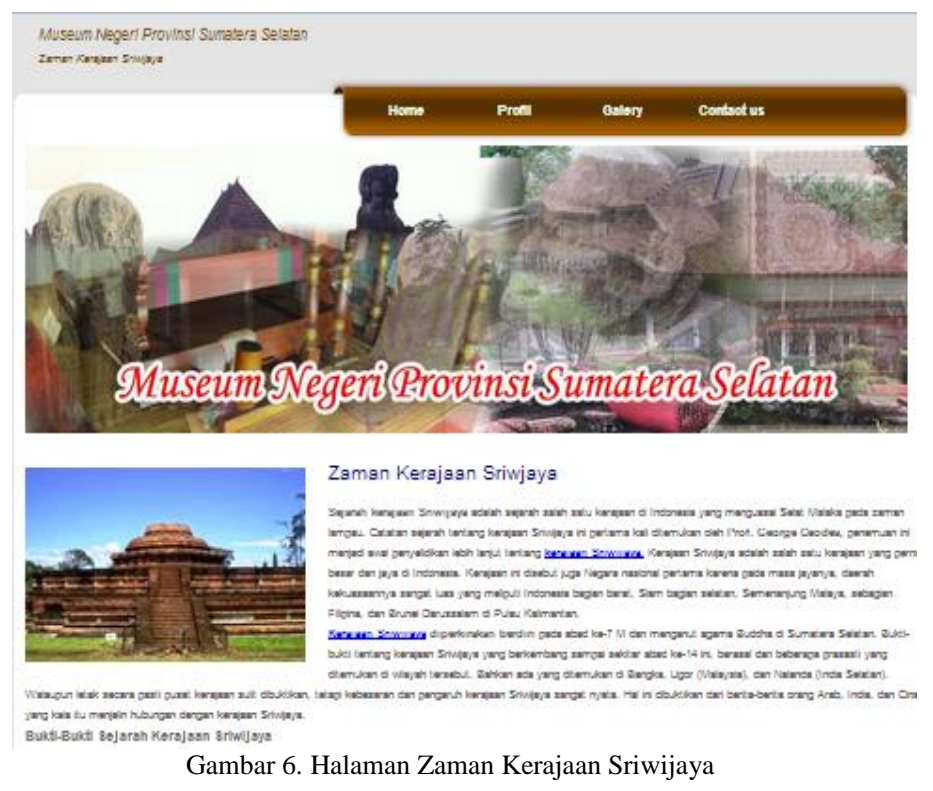

Pada halaman ini memuat sejarah zaman Kerajaan Sriwijaya. Pada halam in juga akan memuat foto - foto peninggal zaman Kerajaan Sriwijaya yang menjadi koleksi pada museum negeri provinsi Sumatera selatan. 

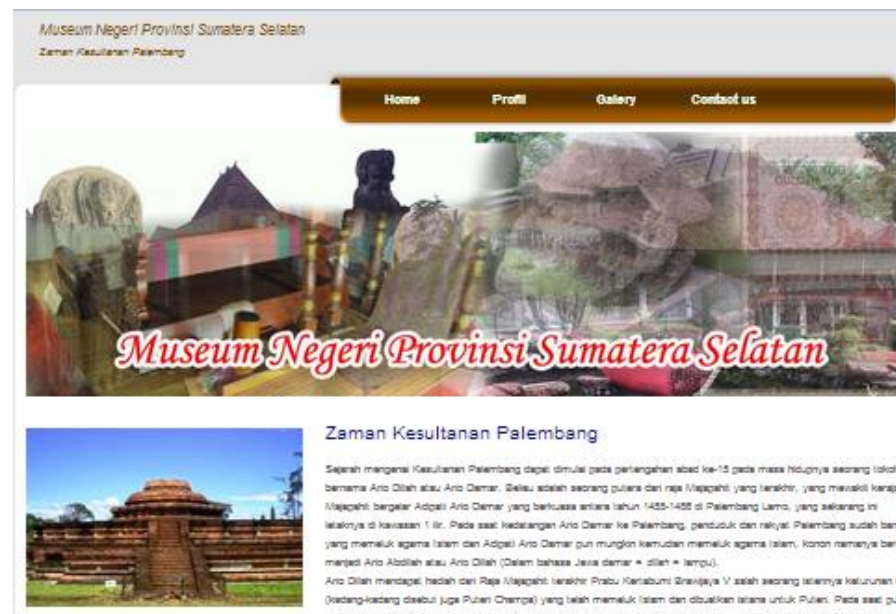

Zaman Kesultanan Palembang

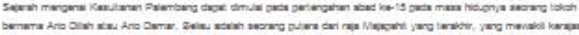

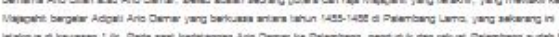

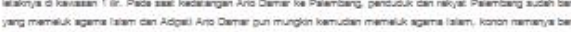

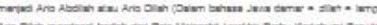

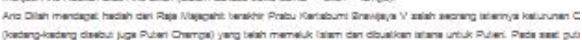

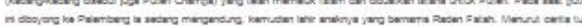

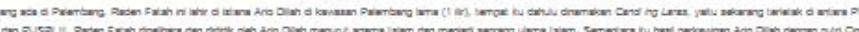

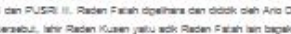

(1)

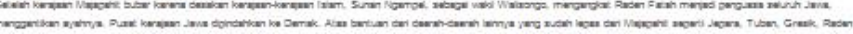

Gambar 7. Halaman Zaman Kesultanan Palembang

Pada halaman ini memuat sejarah zaman Kesultanan Palembang. Pada halam in juga akan memuat foto - foto peninggal zaman kesultana Palembang yang menjadi koleksi pada museum negeri provinsi Sumatera selatan.

\section{PENUTUP}

\section{A. Kesimpulan}

Bersasarkan Penelitian yang telah dilakukan maka dapat ditarik kesimpulan sebagai berikut. Pelmilhan metode untuk membangun sebuah sistem berbasi web sangatlah penting. Estimasi sebuah proyek menjadi sesuatu yang sangat penting sebelum membangun sebuah sistem, karena akan menjadi sebuah acuan dalam membangun sebuah sistem. Website museum nereri Sumater selatan adalah ebauah website yang dibangun untun menjadi media informasi bagi masyarakan berkaitan dengan koleksi - koleksi sejarah yang ada pada museum.

\section{B. Saran}

Hasil dari penellitia ini adalah sebuah website yang masih dapat dikembangkan, arah pengembangan yang diharapkan adalah nantinya website ini dapat dibangun berbasis mobile/Android. Agar ldapat lebih mudah di akses oleh masyarakat.

\section{DAFTAR PUSTAKA}

[1] Schouten, FFJ. 1992 Pengantar didatik Museum

[2] Adi Nugroho, Pemrograman Java untuk Aplikasi Basis Data dengan teknikXp Menggunakan IDE Eclipse. Yogyakarta: Andi, 2007.

[3] M. Rusdiyanto Arief, Pemrograman Web Dinamis Menggunakan PHP \& MySQL.: C.V ANDI OFFSET, 2011.

[4] Andi Sunyoto M.Kom, AJAX Membangun Web dengan TeknologiAsynchronouse JavaScript dan XML.: C.V Andi OFFSET, 2007.

[5] Carroll, E. R. 2005. Estimating Software based on Use Case Points. In Champion To 20ththe Annual ACM SIGPLAN Conference on Object Oriented Programming, System, Languages, and Aplcation (San Diego, CA, USA, October 16 -19 2005).OOPSLA '05. ACM. Newyork, NY, $257-265$.

[6] Boehm, B. and Turner, R. 2004. Balancing Agility and Discipline: Evaluating and Integrating Agile and Plan-Driven Methods. In Proceedings of the 26th international Conference on Software Engineering (May 23 - 28, 2004). International Conference on Software Engineering. IEEE Computer Society, Washington, DC, 718-719. 